\title{
Analytical method development and validation for the estimation of Furosemide an anti-diuretic in Furosemide injection diluted with normal saline in presence of impurities by RP-HPLC
}

\section{Anandakumar Karunakaran ${ }^{1}$, , Sree Iswarya Sudharsan ${ }^{1}$, Ramesh Jayaprakash ${ }^{1}$, Sindhuja Vekatachalam ${ }^{1}$, Senthil Kumar Raju ${ }^{2}$ and Anjana Elampulakkadu ${ }^{1}$}

\author{
${ }^{1}$ Department of Pharmaceutical Analysis. Swamy Vivekanandha College of \\ Pharmacy. Elayampalayam, Tiruchengode. Namakkal (DT). Tamil Nadu. India - 637 \\ 205. Email: anandanalysis@gmail.com. \\ ${ }^{2}$ Department of Pharmaceutical Chemistry. Swamy Vivekanandha College of \\ Pharmacy. Elayampalayam, Tiruchengode. Namakkal (DT). Tamil Nadu. India - 637 \\ 205.
}

\begin{abstract}
This study was aimed to establish a simple, accurate, precise, robust and rapid reverse phase high performance liquid chromatographic method for the estimation of Furosemide in Furosemide injection diluted with normal saline and it was validated as per the parameters mentioned in the ICH guidelines such as system suitability, linearity, accuracy, precision, specificity, ruggedness and robustness and solution stability. The optimized chromatographic HPLC analysis was performed on Waters e2695 system equipped with Inertsil ODS-3V $\mathrm{C}_{18}$ column ( $250 \mathrm{~cm} \times 150 \mathrm{~mm} ; 5 \mu \mathrm{m}$ particle size), with a mixture of $1 \%$ glacial acetic acid and acetonitrile in the ratio of 50\%:50\% $\mathrm{v} / \mathrm{v}$ as the mobile phase, at the flow rate of $1.0 \mathrm{~mL} / \mathrm{min}$. The detection was performed at the wavelength of $272 \mathrm{~nm}$ and the retention time of Furosemide was found to be $7.03 \mathrm{~min}$. The calibration plot gave linear relationship over the concentration range of $10-120 \mu \mathrm{g} / \mathrm{mL}$ with correlation coefficient of $\mathrm{r}^{2}=$ 0.9998. The percentage purity of Furosemide in the given formulation was found to be $103.56 \pm 0.6546$. The amount of Furosemide in the given formulation for intraday and interday was found to be $102.45 \pm 0.2291$ and $102.67 \pm 0.4041$, respectively. The accuracy of the proposed method was determined by recovery studies and was found to be in the range of $100.14 \%$ to $101.01 \%$. This indicates that there is no inteference was observed due to excipients used in formulation. The percentage of RSD was found to be less than 2 for all the parameters. All the impurities peak were separated well and no inteference were found with the retention time of Furosemide. The results of robustness, ruggedness and solution stability were found to be within the acceptance limit. Hence, the

Received

February 18, 2021

Accepted

May 24, 2021

Released

April 30, 2021

Full Text Article

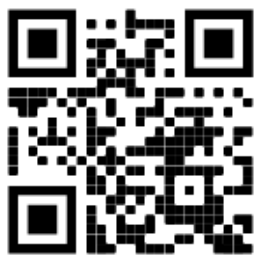

ORCID

0000-0002-9309-9286 Anandakumar Karunakaran 0000-0002-0247-2787 Sree Ishwarya Sudharsan

0000-0002-0710-2398 Ramesh Jayaprakash

0000-0003-1309-3886 Senthil Kumar Raju
\end{abstract}

ISSN 2358-2731/BJBS-2021-0002/2021/8/18/5/35 
developed method was found to be simple, linear, accurate, precise, robust, rapid method for the analysis of Furosemide in Furosemide injection diluted with normal saline. In addition, the main feature of the developed method is lower run time with less solvent consumption.

Keywords: Furosemide; Method development; Furosemide injection; ICH guidelines; Impurities.
0000-0002-9791-7856

Sindhuja

Venkatachalam

0000-0002-2274-1219

Anjana Elampulakkadu

\section{Introduction}

Furosemide (FUR) is a loop diuretic. It is chemically known as 4-chloro-2-[(furan-2-ylmethyl)amino]-5-sulfamoylbenzoic acid. (Figure 1) It is official in various pharmacopoeias (USP-NF, 2008; BP, 2011; EDQM, 2014; IP, 2018). FUR has the following generic names are Fursemide, Aisemide, Beronald, Desdimin, Lasilix and others (Gahandule and Banerjee, 2016). FUR is used for the treatment of Hypertension, chronic congestive heart failure and edema associated with hepatic cirrhosis (Brunton, 2011). The loop diuretics bind to the $\mathrm{Na}^{+}-\mathrm{K}^{+}-2 \mathrm{Cl}^{-}$symporter in the thick ascending limb and interfere with its function resulting in inhibition of transport of electrolytes in this segment of the nephron. Diuretics acting only on the proximal tubules have limited efficacy because the thick ascending limb has an immense capacity for reabsorption of any $\mathrm{Na}^{+}$not reabsorbed at the proximal tubular site. Similarly, diuretics acting primarily on site beyond the thick ascending limb also have limited efficacy as the amount of $\mathrm{Na}^{+}$reaching these sites is very low. On the contrary, loop diuretics which act at the thick ascending limb are highly efficacious and are also known as high ceiling diuretics. Loop diuretics also inhibits $\mathrm{Ca}^{2+}$ $\mathrm{Mg}^{+}$reabsorption in the thick ascending limb by abolishing the transepithelial potential difference that is the main driving force for reabsorption of these cations. Furosemide is the proto-types loop diuretic (Seth and Seth, 2009). The adverse effects of FUR are hyponatraemis, hypokalaemia, hyperuricaemia, Paresthesis, blurred vision and orthostatic hypotension (Brayfield, 2011).

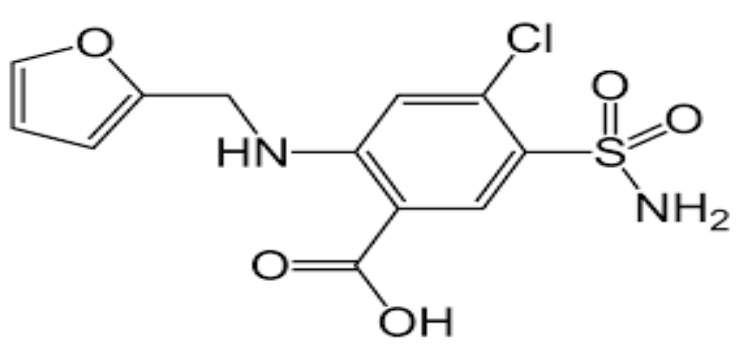

Figure 1. Molecular structure of Furosemide.

Literature survey revealed that, there are several methods have been reported for the estimation of Furosemide in bulk, in pharmaceutical samples and in biological samples either alone or in combination with other drugs. UV spectrophotometric methods was reported for the estimation of FUR in alone (Naveed et al., 2014; Alfred-Ugbenbo et al., 2017), by using AUC method (Gahandule and Banerjee, 2016; Supriya et al., 2018), by charge transfer method (Rani et al., 2017) and in combination with other drugs (Reddy et al., 2013; Darweesh, 2016). HPTLC-densitometry methods following a model approach for 
transfer of TLC screening has developed (Zeng et al., 2018) and for simultaneous determination by using tablet formulation (Kher et al., 2013). Several other analytical methods were reported are as assay of Furosemide, Spironolactone and Canrenone in Human Plasma Samples by HPLC/MS/MS (Sora et al., 2010), FTIR (Gallignania, 2014), ${ }^{1}$ H NMR (Costa et al., 2016) and Capillary electrophoresis (Souza et al., 2019). HPLC methods have been reported for the estimation of FUR by using pharmaceutical dosage form in alone (Roth et al., 1981; Kaynak and Sahln, 2013; Youm and Youan, 2013; Phale, 2017), in combination with other drugs (Maulik et al., 2012; Patil et al., 2012; Ram et al., 2012; Şimşek et al., 2012; Ram et al., 2014; Sila-on et al., 2016; Kassab, 2017; Tandel, 2017; Kumari et al., 2018; Shaikh and Rao, 2018), in biological samples (Lovett et al., 1985; Amin et al., 2010; Mannam and Yallamalli, 2018) and in bovine milk (Shaikh, 1985). Also there are several clinical methods have been developed for FUR (Najiba et al., 2003; Gulbis and Spencer, 2006; Ho and Power, 2010; Chawla et al., 2013; Gandhi et al., 2014; Kitsios et al., 2014; Duffy et al. 2015; Gu et al., 2015; Labriola et al., 2015; Sullivan et al., 2015; Hashemian et al., 2016; Vasco et al., 2016; Widdifield et al., 2016; Chinaca and Nwachukwu, 2017; Dhayat et al., 2017; Matsue et al., 2017; Bove et al., 2018; Lumlertgul et al., 2018; Haddock et al., 2019; Liu et al., 2019; Mose et al., 2019). In all the reported HPLC methods, the runtime for the analysis is more and the analysis was not done in the presence of impurities. So, we aimed to develop a easy, fast and cost effective HPLC method with less run time, less solvent consumption and the analysis of FUR in the presence of listed impurities as per USP. Hence, the objective of the present study was to develop and validate a simple, precise, accurate, less time consuming method for the estimation of FUR in bulk and pharmaceutical preparation in the presence of impurities.

\section{Materials and methods}

\section{Chemicals and reagents}

FUR RS (grade: USP-RS) was used for this study. FUR injection (Brand: Lasix) containing $10 \mathrm{mg} / \mathrm{mL}$ of FUR and sodium chloride viaflo bag (Lable claim: $0.9 \% \mathrm{w} / \mathrm{v}$ ) were purchased from the local pharmacy. FUR RCA and FUR RCB impurites were as used USP-RS grade. FUR-IMP-B, IMP-D and IMP-E were supplied by Simson. European pharmacopoeial grade acetonitrile and sodium hydroxide solution were procured from Merck, ULC/MS-CC/SFC grade glacial acetic acid was procured from biosolve chimie. HPLC grade water was prepared from millipore Milli-Q water purification system as it meets USP requirements. All the chemicals and reagents used in the study were of analytical grade.

\section{Instrumentation and chromatographic condition}

Water e2695 HPLC system was used for liquid chromatography method development and validation; equipped with auto sampler as it consists five carousels of 24 vials each, sample compartment temperature control ranges from $4{ }^{\circ} \mathrm{C}$ to $40{ }^{\circ} \mathrm{C}$ and column compartment temperature control ranges from $20{ }^{\circ} \mathrm{C}$ to $65{ }^{\circ} \mathrm{C}$. The detector consists of UV/PDA and Empower software was used for data processing and evaluation.

Several trials has been performed by using different column, different mobile phase ratio and different injection volume to obtained optimized chromatographic conditions for the method development and validation of FUR e.g. Table 1.

\section{Optimized chromatographic conditions}

Mobile phase composition consists of $1 \%$ glacial acetic acid and acetonitrile in the ratio of $50 \%: 50 \% \mathrm{v} / \mathrm{v}$ were used to elute the sample through Inertsil ODS-3V $\mathrm{C}_{18}$ column ( $250 \mathrm{~mm} \times 4.6 \mathrm{~mm} ; 5 \mu \mathrm{m}$ particle size) as a stationary phase with isocratic elution mode. Check $10 \mu \mathrm{L}$ of samples were injected into it and run time was set at $10 \mathrm{~min}$. The elution 
was detected through a UV/PDA detector at $272 \mathrm{~nm}$ and the chromatograms was observed by using empower software. The operating temperature of the column was set at $25{ }^{\circ} \mathrm{C} \pm$ $2{ }^{\circ} \mathrm{C}$ and the sample compartment temperature was at $15{ }^{\circ} \mathrm{C} \pm 3{ }^{\circ} \mathrm{C}$, flow rate was maintained at $1.0 \mathrm{~mL} / \mathrm{min}$.

\section{Preparation of $1 \%$ glacial acetic acid}

$10 \mathrm{~mL}$ of glacial acetic acid was transferred into $1,000 \mathrm{~mL}$ volumetric flask containing $300 \mathrm{~mL}$ of MilliQ water, diluted up to the volume with MilliQ water, and mixed well. Sonicated for $5 \mathrm{~min}$.

\section{Preparation of mobile phase}

Mixed 1,000 mL of $1 \%$ glacial acetic acid and 1,000 mL of acetonitrile into 2,000 $\mathrm{mL}$ solvent bottle. Sonicated for $5 \mathrm{~min}$. Mobile phase is used as a diluent and blank.

\section{Preparation of standard solution}

Accurately weighed and transferred $50 \mathrm{mg}$ of Furosemide RS into $50 \mathrm{~mL}$ volumetric flask and added $20 \mathrm{~mL}$ of diluent. Dissolved by sonication, diluted up to volume with diluent and mixed well to obtain a concentration of $1 \mathrm{mg} / \mathrm{ml}$. From the above standard stock solution pipette out $1 \mathrm{~mL}$ in to $10 \mathrm{~mL}$ volumetric flask, diluted up to volume with diluent and mixed to obtain a concentration of $100 \mu \mathrm{g} / \mathrm{mL}$.

\section{Preparation of matrix solution}

Transferred $1 \mathrm{~mL}$ of $0.9 \%$ sodium chloride from viaflo bag into $10 \mathrm{~mL}$ volumetric flask and make up to the volume with diluent.

\section{Preparation of sample solution}

Transferred $1 \mathrm{~mL}$ of Furosemide injection into $10 \mathrm{~mL}$ volumetric flask. Diluted upto the volume with NS and mixed well. Pipetted out $1 \mathrm{~mL}$ above solution in to $10 \mathrm{~mL}$ volumetric flask. Diluted upto the volume with diluent and mixed to obtain a concentration of $100 \mu \mathrm{g} / \mathrm{mL}$.

Table 1. Trials of chromatographic conditions.

\begin{tabular}{|c|c|c|c|c|c|}
\hline Trials & Column & Mobile phase & $\begin{array}{c}\text { Injection } \\
\text { Volume }\end{array}$ & Observation & Modification \\
\hline 01 & $\begin{array}{c}\text { Hypersil ODS }{ }_{\mathrm{c} 18}, \\
250 \mathrm{~mm} \times 4.6 \\
\mathrm{~mm} \times 5 \mu \mathrm{m}\end{array}$ & $\begin{array}{l}\text { 1\% GAA: ACN } \\
(70: 30 \% \mathrm{v} / \mathrm{v})\end{array}$ & $20 \mu \mathrm{L}$ & $\begin{array}{l}\text { Peak was eluted at } \\
\mathrm{R}_{\mathrm{t}} 13 \mathrm{~min}\end{array}$ & $\begin{array}{l}\text { Mobile phase } \\
\text { ratio }\end{array}$ \\
\hline 02 & $\begin{array}{l}\text { Hypersil ODS } \\
250 \mathrm{~mm} \times 4.6 \\
\mathrm{~mm} \times 5 \mu \mathrm{m}\end{array}$ & $\begin{array}{l}\text { 1\% GAA: ACN } \\
(50: 50 \% \mathrm{v} / \mathrm{v})\end{array}$ & $20 \mu \mathrm{L}$ & $\begin{array}{l}\mathrm{R}_{\mathrm{t}} \text { was reduced, } \\
\text { but height of the } \\
\text { peak observed at } \\
\text { above } 2 \mathrm{AU}\end{array}$ & $\begin{array}{l}\text { Injection } \\
\text { volume }\end{array}$ \\
\hline 03 & $\begin{array}{l}\text { Hypersil ODS } \\
250 \mathrm{~mm} \times 4.6 \\
\mathrm{~mm} \times 5 \mu \mathrm{m}\end{array}$ & $\begin{array}{l}\text { 1\% GAA: ACN } \\
(50: 50 \% \mathrm{v} / \mathrm{v})\end{array}$ & $5 \mu \mathrm{L}$ & $\begin{array}{c}\text { Peak eluted at } \\
\text { below } 2 \text { AU and for } \\
\text { further } \\
\text { conformation }\end{array}$ & $\begin{array}{l}\text { Injection } \\
\text { volume }\end{array}$ \\
\hline 04 & $\begin{array}{c}\text { Hypersil ODS }{ }_{\mathrm{c} 18} \\
250 \mathrm{~mm} \times 4.6 \\
\mathrm{~mm} \times 5 \mu \mathrm{m}\end{array}$ & $\begin{array}{l}\text { 1\% GAA: ACN } \\
(50: 50 \% \mathrm{v} / \mathrm{v})\end{array}$ & $10 \mu \mathrm{L}$ & $\begin{array}{c}\text { In NS, hump was } \\
\text { observed at the } \mathrm{R}_{\mathrm{t}} \text { of } \\
\text { FUR }\end{array}$ & Column \\
\hline
\end{tabular}


Table 1. Continued.

\begin{tabular}{|c|c|c|c|c|c|}
\hline Trials & Column & $\begin{array}{l}\text { Mobile } \\
\text { phase }\end{array}$ & $\begin{array}{l}\text { Injection } \\
\text { Volume }\end{array}$ & Observation & Modification \\
\hline 05 & $\begin{array}{c}\text { X- Bridge }{ }_{c 8}, 250 \\
\mathrm{~mm} \times 4.6 \mathrm{~mm} \times 5 \\
\mu \mathrm{m}\end{array}$ & $\begin{array}{l}\text { 1\% GAA: ACN } \\
(50: 50 \% \mathrm{v} / \mathrm{v})\end{array}$ & $10 \mu \mathrm{L}$ & $\begin{array}{l}\text { No hump observed } \\
\text { and for further } \\
\text { conformation }\end{array}$ & Column \\
\hline 06 & $\begin{array}{c}\text { Hypersil BDS } \mathrm{c} 18, \\
250 \mathrm{~mm} \times 4.6 \\
\mathrm{~mm} \times 5 \mu \mathrm{m}\end{array}$ & $\begin{array}{l}\text { 1\% GAA: ACN } \\
(50: 50 \% \mathrm{v} / \mathrm{v})\end{array}$ & $10 \mu \mathrm{L}$ & $\begin{array}{l}\text { Hump was } \\
\text { observed at the }\end{array}$ & $\begin{array}{l}\text { Matrix solution } \\
\text { and Sample } \\
\text { prepared in } \\
\text { matrix were } \\
\text { used } \\
\end{array}$ \\
\hline 07 & $\begin{array}{c}\text { Hypersil BDS }{ }_{\mathrm{c} 18}, \\
250 \mathrm{~mm} \times 4.6 \\
\mathrm{~mm} \times 5 \mu \mathrm{m}\end{array}$ & $\begin{array}{l}\text { 1\% GAA: ACN } \\
(50: 50 \% \mathrm{v} / \mathrm{v})\end{array}$ & $10 \mu \mathrm{L}$ & $\begin{array}{l}\text { No hump observed } \\
\text { and for further } \\
\text { conformation }\end{array}$ & $\begin{array}{l}\text { Mobile phase } \\
\quad \text { ratio }\end{array}$ \\
\hline 08 & $\begin{array}{c}\text { Hypersil BDS }{ }_{\mathrm{c} 18} \\
250 \mathrm{~mm} \times 4.6 \\
\mathrm{~mm} \times 5 \mu \mathrm{m}\end{array}$ & $\begin{array}{l}\text { 1\% GAA: ACN } \\
(40: 60 \% \mathrm{v} / \mathrm{v})\end{array}$ & $10 \mu \mathrm{L}$ & $\begin{array}{c}\text { It elute the peak at } \\
\text { lesser } R_{t} \text {. }\end{array}$ & $\begin{array}{l}\text { Compare two } \\
\text { different } \\
\text { Mobile phase } \\
\text { ratio } \\
\end{array}$ \\
\hline 09 & $\begin{array}{l}\text { Hypersil ODS }{ }_{\mathrm{c} 18} \\
250 \mathrm{~mm} \times 4.6 \\
\mathrm{~mm} \times 5 \mu \mathrm{m}\end{array}$ & $\begin{array}{l}\text { 1\% GAA: ACN } \\
\text { (40:60\% v/v) } \\
\text { 1\% GAA: ACN } \\
(50: 50 \% \mathrm{v} / \mathrm{v})\end{array}$ & $10 \mu \mathrm{L}$ & $\begin{array}{c}\text { 1\% GAA: ACN } \\
(50: 50 \% \mathrm{v} / \mathrm{v}), \text { gives } \\
\text { better response and } \\
\text { for further } \\
\text { conformation }\end{array}$ & Column \\
\hline 10 & $\begin{array}{l}\text { XTerra, } 150 \mathrm{~mm} \\
\text { x } 3.9 \mathrm{~mm} \times 5 \mu \mathrm{m}\end{array}$ & $\begin{array}{l}\text { 1\% GAA: ACN } \\
(50: 50 \% \mathrm{v} / \mathrm{v})\end{array}$ & $10 \mu \mathrm{L}$ & $\begin{array}{l}\text { Reducing the length } \\
\text { of the column will } \\
\text { affect robustness }\end{array}$ & Column \\
\hline 11 & $\begin{array}{l}\text { Hypersil ODS }{ }_{\mathrm{c} 18} \\
250 \mathrm{~mm} \times 4.6 \\
\mathrm{~mm} \times 5 \mu \mathrm{m}\end{array}$ & $\begin{array}{l}\text { 1\% GAA: ACN } \\
(50: 50 \% \mathrm{v} / \mathrm{v})\end{array}$ & $10 \mu \mathrm{L}$ & $\begin{array}{c}\text { It gives sharp peak. } \\
\text { So, all the } \\
\text { impurities were } \\
\text { injected separately }\end{array}$ & - \\
\hline 12 & $\begin{array}{c}\text { Hypersil ODS }{ }_{\mathrm{c} 18}, \\
250 \mathrm{~mm} \times 4.6 \\
\mathrm{~mm} \times 5 \mu \mathrm{m} \\
\end{array}$ & $\begin{array}{l}\text { 1\% GAA: ACN } \\
(50: 50 \% \mathrm{v} / \mathrm{v})\end{array}$ & $10 \mu \mathrm{L}$ & $\begin{array}{l}\text { FUR_RCA peak not } \\
\text { separated well }\end{array}$ & $\begin{array}{l}\text { Mobile phase } \\
\text { ratio }\end{array}$ \\
\hline 13 & $\begin{array}{c}\text { Hypersil ODS } \mathrm{c18}, \\
250 \mathrm{~mm} \times 4.6 \\
\mathrm{~mm} \times 5 \mu \mathrm{m} \\
\end{array}$ & $\begin{array}{l}\text { 1\% GAA: ACN } \\
(60: 40 \% \mathrm{v} / \mathrm{v})\end{array}$ & $10 \mu \mathrm{L}$ & $\begin{array}{c}\text { FUR_RCA peak } \\
\text { interfered at } \mathrm{R}_{\mathrm{t}} \text { of } \\
\text { FUR } \\
\end{array}$ & $\begin{array}{l}\text { Mobile phase } \\
\text { ratio }\end{array}$ \\
\hline 14 & $\begin{array}{c}\text { Hypersil ODS }{ }_{\mathrm{c} 18} \\
250 \mathrm{~mm} \times 4.6 \\
\mathrm{~mm} \times 5 \mu \mathrm{m}\end{array}$ & $\begin{array}{l}\text { 1\% GAA: ACN } \\
(70: 30 \% \mathrm{v} / \mathrm{v})\end{array}$ & $10 \mu \mathrm{L}$ & $\begin{array}{c}\text { FUR_RCA peak } \\
\text { interfered at } \mathrm{R}_{\mathrm{t}} \text { of } \\
\text { FUR }\end{array}$ & $\begin{array}{l}\text { Mobile phase } \\
\text { ratio \& Column }\end{array}$ \\
\hline 15 & $\begin{array}{c}\text { X-Bridge с8, } 250 \\
\mathrm{~mm} \times 4.6 \mathrm{~mm} \times 5 \\
\mu \mathrm{m}\end{array}$ & $\begin{array}{l}\text { 1\% GAA: ACN } \\
(50: 50 \% \mathrm{v} / \mathrm{v})\end{array}$ & $10 \mu \mathrm{L}$ & $\begin{array}{l}\text { FUR_RCA peak not } \\
\text { separated well }\end{array}$ & Column \\
\hline 16 & $\begin{array}{c}\text { Inertsil ODS-3V, } \\
250 \mathrm{~mm} \times 4.6 \\
\mathrm{~mm} \times 5 \mu \mathrm{m}\end{array}$ & $\begin{array}{l}\text { 1\% GAA: ACN } \\
(50: 50 \% \mathrm{v} / \mathrm{v})\end{array}$ & $10 \mu \mathrm{L}$ & $\begin{array}{l}\text { FUR_RCA peak not } \\
\text { separated well }\end{array}$ & $\begin{array}{c}\text { Optimized } \\
\text { chromatograp } \\
\text { hic condition }\end{array}$ \\
\hline
\end{tabular}

\section{Preparation of impurity solution}

Accurately weighed and transferred $5 \mathrm{mg}$ of FUR-RCA, FUR-RCB, FUR-IMP-B, FUR-IMP-D and FUR-IMP-E individually and transferred into their respective $50 \mathrm{~mL}$ volumetric flasks. Added $20 \mathrm{~mL}$ of diluent dissolved by sonication and diluted up to volume with diluent. From the above, stock solution pipette out $0.1 \mathrm{~mL}$ in to $10 \mathrm{~mL}$ volumetric flask, diluted up to volume with diluent and mixed well. 


\section{Preparation of impurity spiked solution}

Pipetted out $1 \mathrm{~mL}$ of stock solution (standard and sample) and $0.1 \mathrm{~mL}$ of FUR-RCA, FUR-RCB, FUR-IMP-B, FUR-IMP-D and FUR-IMP-E stock solutions into $10 \mathrm{~mL}$ volumetric flask. Diluted upto the volume with diluent and mixed well.

\section{Preparation of resolution solution}

Diluted $5 \mathrm{~mL}$ of standard stock solution and $0.25 \mathrm{~mL}$ of FUR-RCA into $50 \mathrm{~mL}$ volumetric flask. Dissolved and diluted upto the volume with diluent and mixed well.

\section{Selection of wavelength}

$10 \mu \mathrm{g} / \mathrm{mL}$ of standard stock solution was scanned between $200 \mathrm{~nm}$ and $400 \mathrm{~nm}$ and the spectrum was recorded. From the spectrum, $272 \mathrm{~nm}$ was selected as detection wavelength e. g. Figure 2.

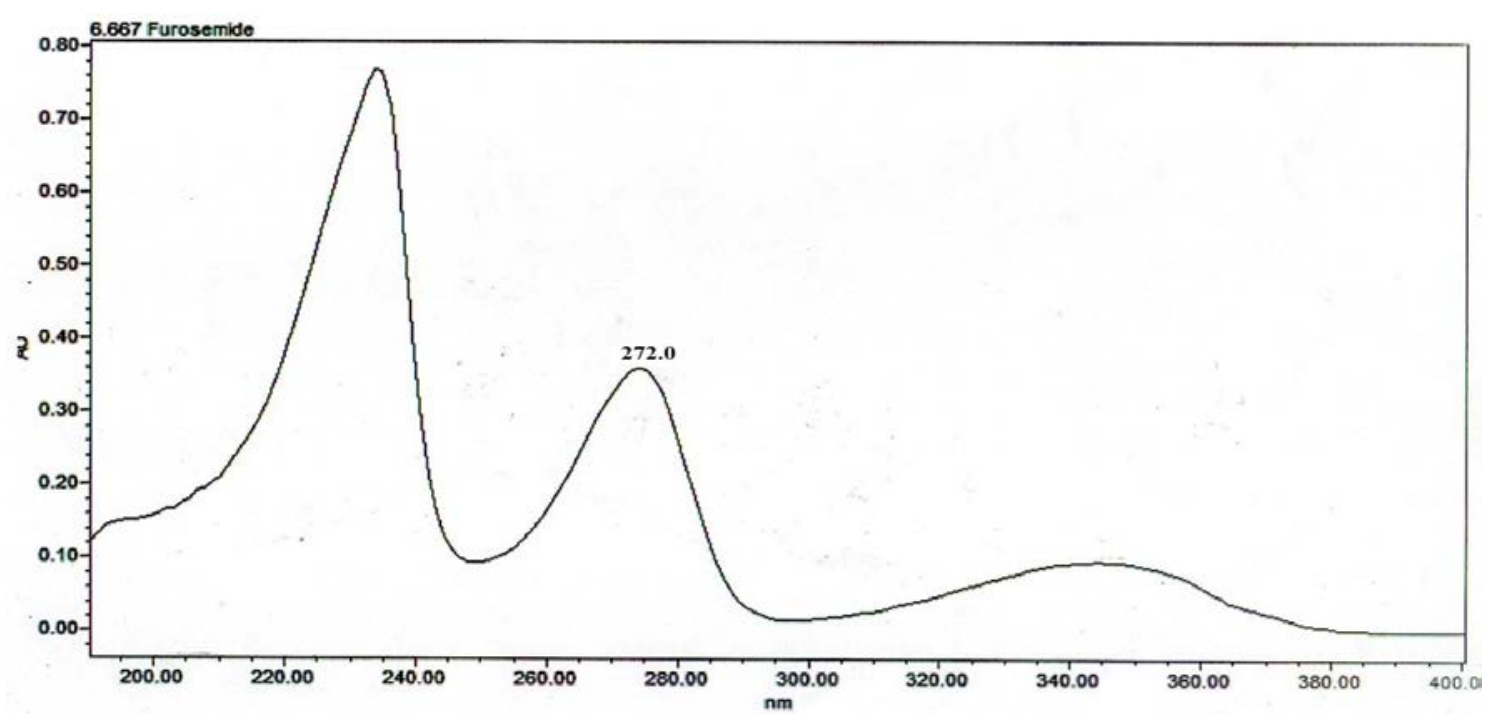

Figure 2. UV spectrum of Furosemide in mobile phase.

\section{Method validation}

The proposed method was developed and validated as per the ICH guidelines (Code Q2 (R1), 2015). The following parameters were evaluated as given below.

\section{System Suitability}

The system suitability of the method was assessed to verify whether the analytical system is working properly or it can give accurate and precise results, by injecting the six replicates of the standard solution. System suitability parameters like USP plate count, USP tailing factor, USP Resolution, retention time of six replicates were calculated. The resolution between FUR RS and FUR-RCA peak was calculated.

\section{Linearity}

Linearity of the method was assessed by analyzing standard stock solution of FUR at different concentrations. A calibration curve was plotted, as the peak area on Y-axis against the concentration on X-axis, of FUR was linear in the concentration range of $10-120 \mu \mathrm{g} / \mathrm{mL}$ at $272 \mathrm{~nm}$. The optical characteristics such as correlation coefficient, slope, intercept and residual sum of squares were calculated. 


\section{Precision}

Precision studies were done in terms of repeatability and intermediate precision. Repeatability of the method was confirmed by the analysis of formulation (sample solution $-60 \mu \mathrm{g} / \mathrm{mL}$ ) was repeated for six times with same concentration. Intermediate precision of the method was confirmed by analysis the formulation (sample solution $60 \mu \mathrm{g} / \mathrm{mL}$ ) was repeated for three times in a same day (Intraday) and in three consecutive days (interday). The amount of drug present in the formulation was calculated. The mean, standard deviation and percentage of RSD for six replicate was also reported.

\section{Accuracy}

Accuracy of the method was determined by recovery studies at three different concentration levels $(80 \%, 100 \%$, and $120 \%)$ and three samples from each concentration were injected. The amount of drug recovered and percentage of RSD was calculated.

\section{Specificity}

Specificity is the ability to measure and specifically the analyte of interest in the presence of other components that may be expected to be present in the sample matrix. The method was evaluated by injecting $10 \mu \mathrm{L}$ solutions of standard, sample, blank and impurities as FUR-RCA, FUR-RCB, FUR-IMP-B, FUR-IMP-D and FUR-IMP-E. Interference was observed. Purity angle Purity threshold was measured by using chromatographic software.

\section{Robustness}

The robustness is the ability of a method to remain unaffected by small deliberate changes in chromatographic parameters. The mean, SD and percentage of RSD were calculated. The variations were done in chromatographic conditions are

Flow rate was varied by $\pm 0.2 \mathrm{~mL} / \mathrm{min}$,

Column temperature was varied by $\pm 5^{\circ} \mathrm{C}$,

Mobile phase composition was varied by $\pm 10 \%$ on organic and aqueous phase.

\section{Ruggedness}

Ruggedness of the proposed method was determined by analyzing six replicates of sample solution at nominal concentration by two analysts to check the reproducibility of the test results. The amount of drug present in the formulation was calculated. The mean, standard deviation and percentage of RSD for six replicate was also reported.

\section{Solution stability}

Stability of the analytical solutions such as blank, matrix, resolution solution, standard solution and sample solution were verified by analyzing initially and at different time intervals. Those solutions were stored in HPLC auto sampler at $15{ }^{\circ} \mathrm{C}$ and in room temperature. The percentage of RSD was calculated.

\section{Results and discussion}

\section{Method development and optimization}

A simple, precise, accurate and rapid HPLC method for the assay of Furosemide injection diluted with normal saline was developed. The UV spectrum for FUR in mobile phase was recorded. The $\lambda$ max of FUR was found to be $234 \mathrm{~nm}$ and $272 \mathrm{~nm}$. At $234 \mathrm{~nm}$ the absorbance of FUR was high. This may cause very high peak height. When compare to this, $272 \mathrm{~nm}$ was given less peak area. Hence, $272 \mathrm{~nm}$ was selected as a detection wavelength. Several trials have been performed to optimize the chromatographic conditions. To optimize the injection volume, different volumes were used. While using 
$20 \mu \mathrm{L}$, the peak was eluted at the height of above $2 \mathrm{AU}$, in $5 \mu \mathrm{L}$ the peak height was observed below $2 \mathrm{AU}$. But the peak achieves optimum height when $10 \mu \mathrm{L}$ solution was injected.

Different types of column were used to achieve the optimum elution of the Furosemide peak and impurities peak. In Hypersil ODS $\mathrm{C}_{18}$ column, sharp peak was observed but hump was seen in NS. RCA peak was not separated well and it eluted at the retention time of FUR peak. In X-Bridge $\mathrm{C}_{8}$ column, the reduction in carbon eluted the peak at earlier retention time and RCA peak interfered at the retention time of FUR. In Hypersil BDS $\mathrm{C}_{18}$ column, peak shape was good but hump was observed in NS at the retention time of the Furosemide Peak. In XTerra $(150 \mathrm{~mm})$ column, reduction in column length eluted the peak at retention time of about 2 mins but it will affect the robustness. Finally, Inertsil ODS-3V, FUR was selected as the stationary phase and the peak shape was good and no interference was observed at the retention time of FUR. All the impurities were also separated well.

For better separation of Furosemide peak and impurities peak, mobile phase composition ratio were tried. In the ratio of $1 \%$ glacial acetic acid: acetonitrile $70: 30 \%$ v/v), FUR peak shape was good. However, the RCA peak was not completely separated it has some interference at the retention time of the FUR. In the ratio of $1 \%$ glacial acetic acid: acetonitrile $(40: 60 \% \mathrm{v} / \mathrm{v})$, peak was eluted at earlier retention time and also they have a chance to observe interference at the retention time of FUR peak due to impurities. In the ratio of $1 \%$ glacial acetic acid: acetonitrile $(60: 40 \% \mathrm{v} / \mathrm{v})$, the RCA peak was not separated it eluted at the retention time of the Furosemide peak. In the ratio of $1 \%$ glacial acetic acid: acetonitrile $(50: 50 \% \mathrm{v} / \mathrm{v})$, sharp peak was obtained and found optimum elution time. All the impurities were separated well. No interference was observed at the retention time of the FUR peak due to blank, matrix and impurities. Hence, 1\% glacial acetic acid: acetonitrile (50:50 v/v) was selected as an appropriate mobile phase composition for the FUR elution. The optimized chromatogram is shown e.g. Figure 3.

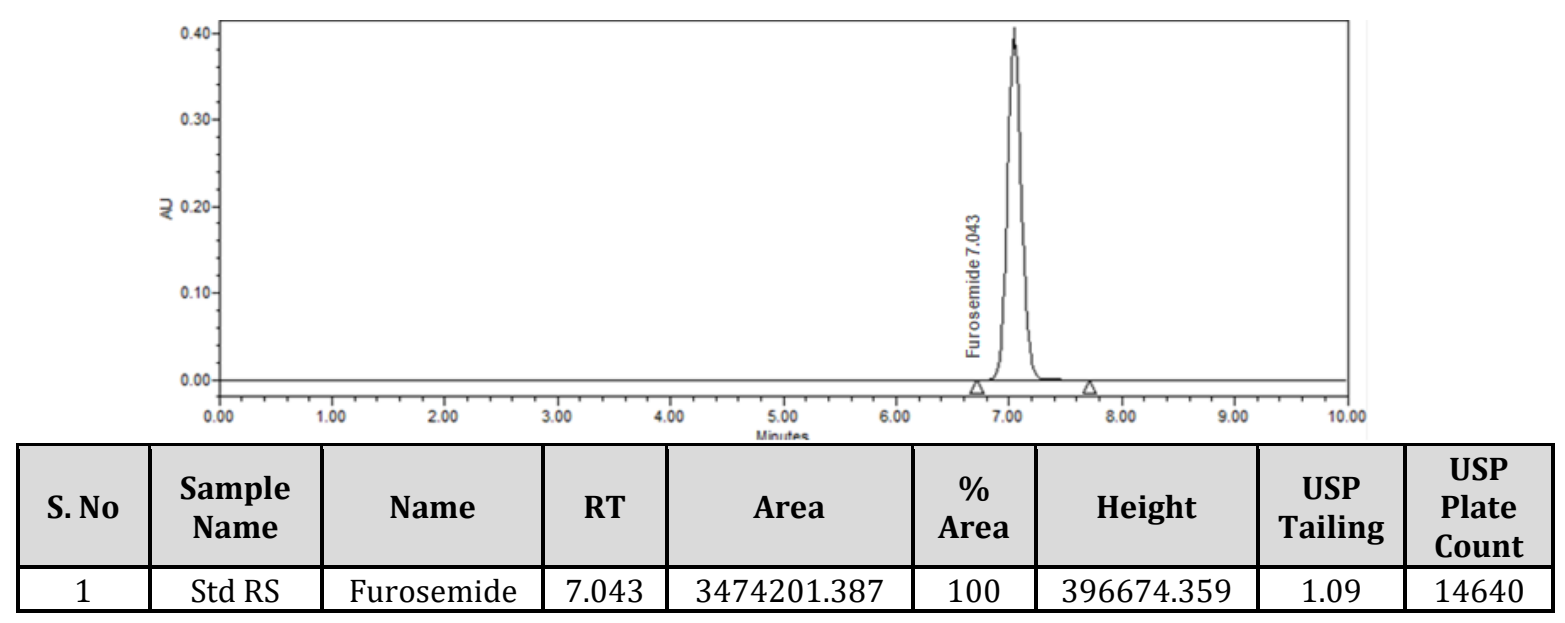

Figure 3. Optimized chromatogram of Furosemide.

\section{Method validation - System suitability}

No peak was observed due to blank and matrix. Retention time of FUR was found to be $7.043 \mathrm{~min}$ for average six replicate injection of standard solution at nominal concentration. USP resolution between FUR and UR_RCA peak was found to be 3.54. All the system suitability parameters meets within the acceptance limit e.g. Table 2. 
Table 2. System suitability results for Furosemide.

\begin{tabular}{|l|c|c|}
\hline SST Parameters & Observed Results & Acceptance Criteria \\
\hline Blank & No peak & - \\
\hline Matrix & No peak & - \\
\hline Capacity factor & & - \\
\hline Retention Time & 7.043 & NLT 2.0 \\
\hline Tailing Factor & 1.11 & $>2500$ \\
\hline Theoretical Plates & 14839 & $98 \%$ to $102 \%$ \\
\hline $\begin{array}{l}\text { Control \% Agreement } \\
\text { Resolution (Between RCA Peak and } \\
\text { Furosemide Peak) }\end{array}$ & $99 \%$ & NLT 2.0 \\
\hline Assymmetry factor & 3.54 & NMT 2.0 \\
\hline HETP & & - \\
\hline
\end{tabular}

\section{Linearity}

The calibration curve was obtained using the least square regression procedure. The developed method was found to be linear in the concentration range of $10-120 \mu \mathrm{g} / \mathrm{mL}$ at $272 \mathrm{~nm}$. The linearity chromatograms are shown e.g. Figure 4 and the calibration graph is shown e.g. Figure 5. The optical characteristics data are given e.g. Table 3.

Table3. Optical characteristics of Furosemide.

\begin{tabular}{|l|c|}
\hline Parameters & Observation \\
\hline Detection Wavelength $(\mathrm{nm})$ & $272 \mathrm{~nm}$ \\
\hline Correlation Coefficient(r) & 0.9998 \\
\hline Regression equation $(\mathrm{y}=\mathrm{mx}+\mathrm{c})$ & $\mathrm{Y}=33746 \mathrm{x}-59020$ \\
\hline Slope (m) & 33746 \\
\hline Intercept (c) & 59020 \\
\hline Correlation Coefficient(r) & 0.9998 \\
\hline RSS & 0.0000003653 \\
\hline
\end{tabular}

\section{Precision} precision.

The precision of the method was confirmed by repeatability and intermediate

\section{Repeatability}

The repeatability of the method was confirmed by the repeated analysis of formulation for six times. The percentage purity of FUR in formulation was found to be $103.56 \pm 0.6546$. The percentage of RSD was found to be 0.6321 . The low percentage of RSD value indicates that the method was more precise. The result of the analysis of formulation is shown e.g. Table 4. 


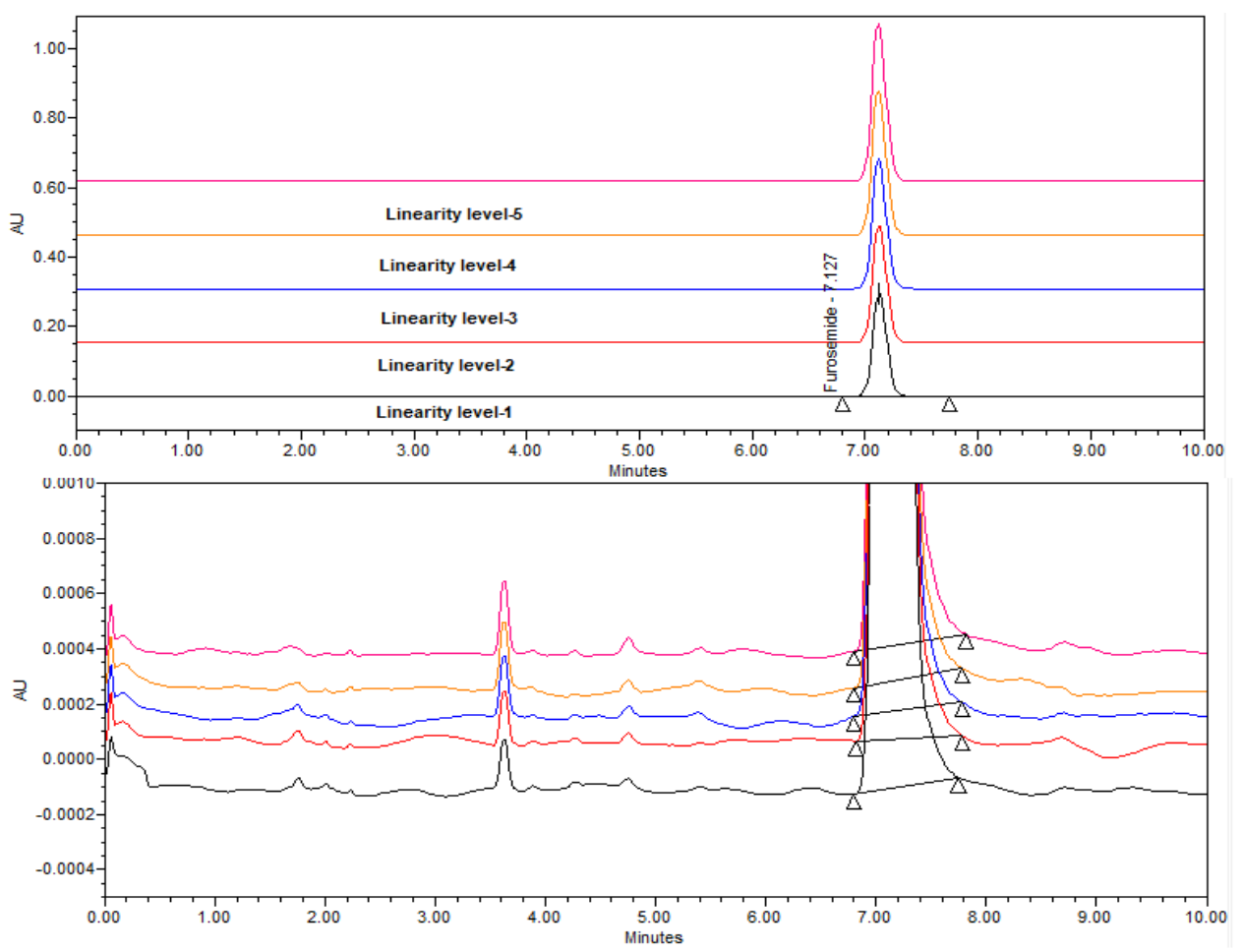

Figure 4. Linearity chromatogram of Furosemide.

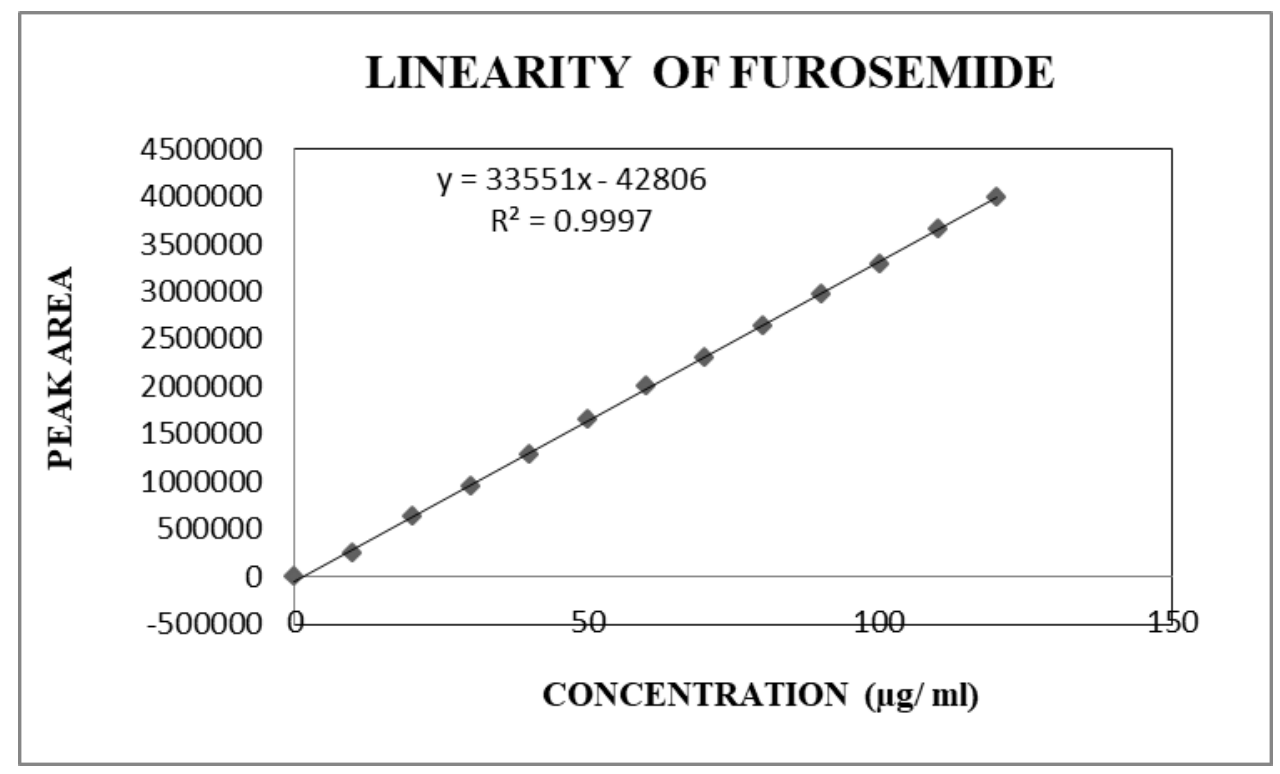

Figure 5. Calibration curve of Furosemide. 
Table 4. Analysis of formulation for Furosemide.

\begin{tabular}{|c|c|c|c|c|c|c|c|c|}
\hline Sample & $\begin{array}{c}\text { Experimental } \\
\text { concentratio } \\
n(\mathrm{mg} / \mathrm{mL})\end{array}$ & $\begin{array}{l}\text { Average area } \\
\text { of Furosemide }\end{array}$ & $\begin{array}{c}\% \\
\text { assay* }\end{array}$ & Mean & SD & $\begin{array}{c}\% \\
\text { RSD }\end{array}$ & SE & CI \\
\hline 1 & 0.1025 & 3486691.269 & 103.31 & \multirow{6}{*}{103.56} & \multirow{6}{*}{0.6546} & \multirow{6}{*}{0.6321} & \multirow{6}{*}{0.2672} & \multirow{6}{*}{$\begin{array}{l}102.87 \\
\text { to } \\
104.25\end{array}$} \\
\hline 2 & 0.1025 & 3486130.591 & 103.32 & & & & & \\
\hline 3 & 0.1024 & 3482503.623 & 103.18 & & & & & \\
\hline 4 & 0.1024 & 3482978.536 & 103.20 & & & & & \\
\hline 5 & 0.1031 & 3509203.983 & 104.88 & & & & & \\
\hline 6 & 0.1026 & 3492191.677 & 103.48 & & & & & \\
\hline
\end{tabular}

* Mean of six observations.

\section{Intermediate precision}

The intermediate precision was done by intraday and interday analysis. The analysis of formulation was repeated for three times on the same day and on three consecutive days. The percentage of RSD value for intraday and interday analysis was found to be 0.2236 and 0.3936 respectively. The lowpercentage of RSD values denys intermediate precision of method has confirmed e.g. Table 5.

Table 5. Intraday and interday analysis.

\begin{tabular}{|c|c|c|c|c|c|c|c|c|c|}
\hline & Sample & $\begin{array}{c}\text { Labelled } \\
\text { amount } \\
(\mathrm{mg} / \mathrm{mL})\end{array}$ & $\begin{array}{l}\text { Amount } \\
\text { found } \\
(\mathrm{mg} / \mathrm{mL})\end{array}$ & $\begin{array}{c}\% \\
\text { assay }^{*}\end{array}$ & Mean & SD & $\%$ RSD & SE & CI \\
\hline \multirow{3}{*}{ Intraday } & 1 & 0.1 & 0.1025 & 102.25 & \multirow{3}{*}{102.45} & \multirow{3}{*}{0.2291} & \multirow{3}{*}{0.2236} & \multirow{3}{*}{0.1323} & \multirow{3}{*}{$\begin{array}{c}101.88 \\
\text { to } \\
103.02 \\
\end{array}$} \\
\hline & 2 & 0.1 & 0.1024 & 102.40 & & & & & \\
\hline & 3 & 0.1 & 0.1027 & 102.70 & & & & & \\
\hline \multirow{3}{*}{ Interday } & 1 & 0.1 & 0.1023 & 102.30 & \multirow{3}{*}{102.67} & \multirow{3}{*}{0.4041} & \multirow{3}{*}{0.3936} & \multirow{3}{*}{0.2334} & \multirow{3}{*}{$\begin{array}{c}101.67 \\
\text { to } \\
103.67\end{array}$} \\
\hline & 2 & 0.1 & 0.1026 & 102.60 & & & & & \\
\hline & 3 & 0.1 & 0.1031 & 103.10 & & & & & \\
\hline
\end{tabular}

* Means of six observations

\section{Accuracy}

The accuracy of the method is confirmed by recovery analysis. To the pre- analyzed formulation, known quantities of the standard drugs were added at three different concentrations such as $80 \%, 100 \%$ and $120 \%$ concentration. The percentage of recovery of Furosemide was found in the range of $100.14 \%$ to $101.01 \%$. The percentage of RSD values were found to be 0.2770 . The low percentage of RSD values indicate that method was more accurate and there was no interference observed due to excipients present in the formulation e.g. Table 6. 
Table 6. Recovery analysis of Furosemide.

\begin{tabular}{|c|c|c|c|c|c|c|c|}
\hline $\begin{array}{c}\text { Sample } \\
\text { level }\end{array}$ & $\begin{array}{c}\text { Theoretical } \\
\text { concentratio } \\
\text { n }(\mathrm{mg} / \mathrm{mL})\end{array}$ & $\begin{array}{c}\text { Experimental } \\
\text { Concentratio } \\
n(\mathrm{mg} / \mathrm{mL})\end{array}$ & $\begin{array}{c}\% \\
\text { recovery* }\end{array}$ & SD & \% RSD & SE & CI \\
\hline $80 \%-1$ & \multirow{3}{*}{0.0797} & 0.0804 & 100.64 & \multirow{9}{*}{0.2787} & \multirow{9}{*}{0.2770} & \multirow{9}{*}{0.0923} & \multirow{9}{*}{$\begin{array}{l}100.39 \\
\text { to } \\
100.82\end{array}$} \\
\hline $80 \%-2$ & & 0.0806 & 100.80 & & & & \\
\hline $80 \%-3$ & & 0.0804 & 100.65 & & & & \\
\hline $100 \%-1$ & \multirow{3}{*}{0.0996} & 0.1000 & 100.14 & & & & \\
\hline $100 \%-2$ & & 0.1009 & 101.01 & & & & \\
\hline $100 \%-3$ & & 0.1007 & 100.82 & & & & \\
\hline $120 \%-1$ & \multirow{3}{*}{0.1195} & 0.1201 & 100.24 & & & & \\
\hline $120 \%-2$ & & 0.1205 & 100.54 & & & & \\
\hline $120 \%-3$ & & 0.1207 & 100.74 & & & & \\
\hline & & Mean & 100.61 & & & & \\
\hline
\end{tabular}

* Means of six observations.

\section{Specificity}

Specificity was evaluated by comparing the chromatograms of blank, matrix solution, standard solution and sample solution. It can be observed that there are no coeluting peak at the retention time of FUR peak e.g. Figure 6-9. Further, all five impurities and impurities spiked standard and sample solutions were injected separately for the identification of their retention time. The entire impurities peak were separated well e.g. Figure 10. The peak purity of Furosemide was also measured by using chromatographic software which shows purity angle is less than the purity threshold. This result indicates that the peak of the analyte was pure and this confirmed the specificity of the method.

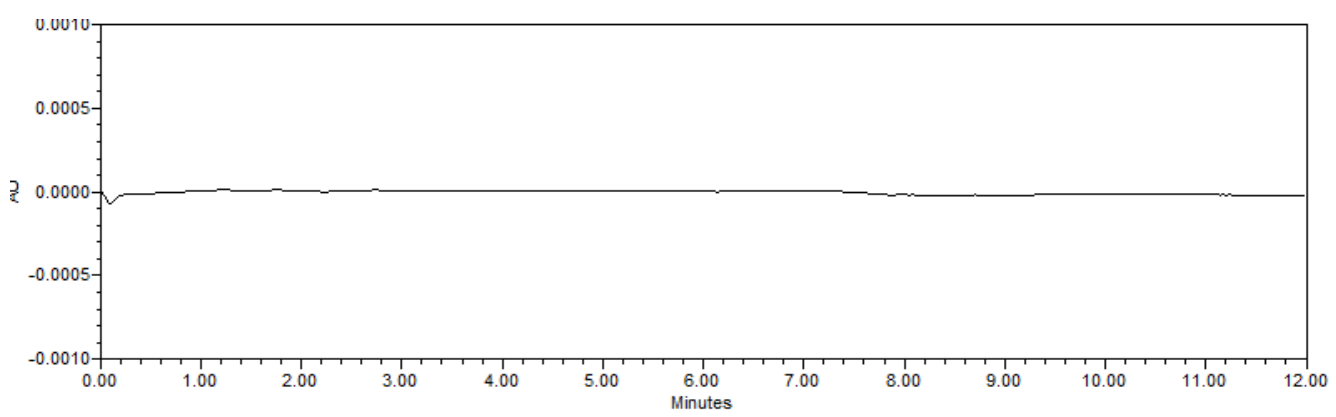

Figure 6. Chromatogram for blank. 


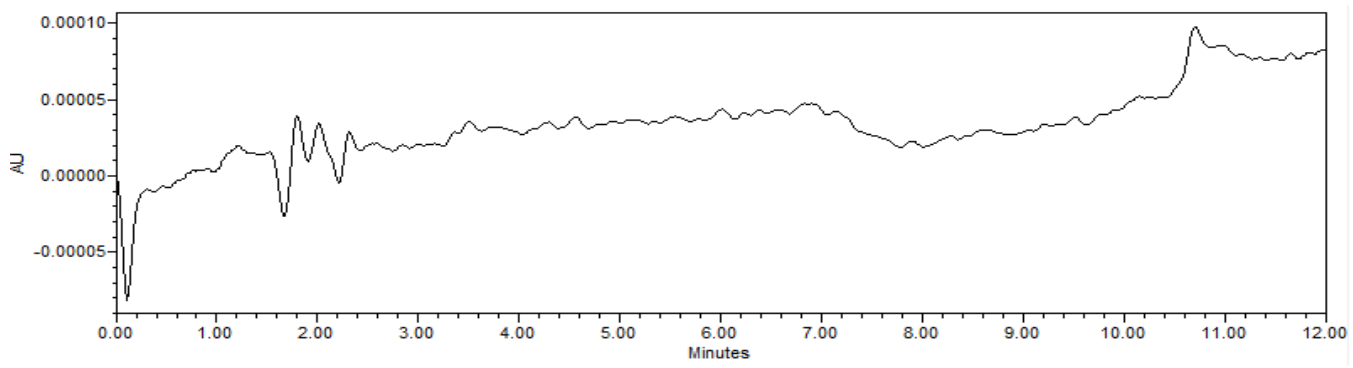

Figure 7. Chromatogram for matrix solution.
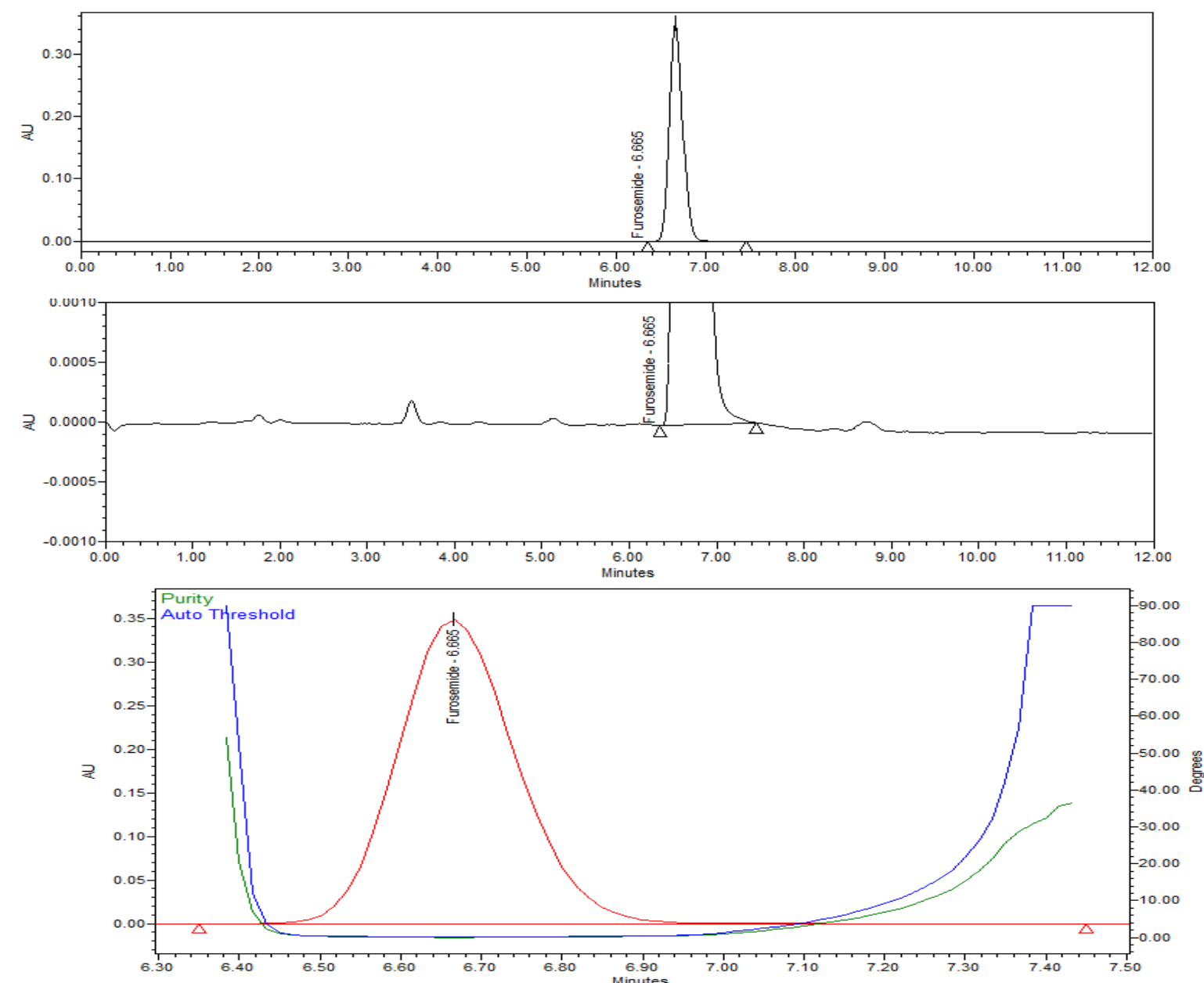

\begin{tabular}{|c|c|c|c|c|c|c|c|c|}
\hline $\begin{array}{c}\text { S. } \\
\text { No }\end{array}$ & $\begin{array}{c}\text { Sample } \\
\text { name }\end{array}$ & Name & RT & Area & $\begin{array}{c}\text { \% } \\
\text { Area }\end{array}$ & Height & $\begin{array}{c}\text { Purity } \\
\text { angle }\end{array}$ & $\begin{array}{c}\text { Purity } \\
\text { threshold }\end{array}$ \\
\hline 1 & Std RS & Furosemide & 6.665 & 3588209.437 & 100 & 348556.297 & 1.110 & 0.253 \\
\hline
\end{tabular}

Figure 8. Chromatogram for standard solution of Furosemide. 


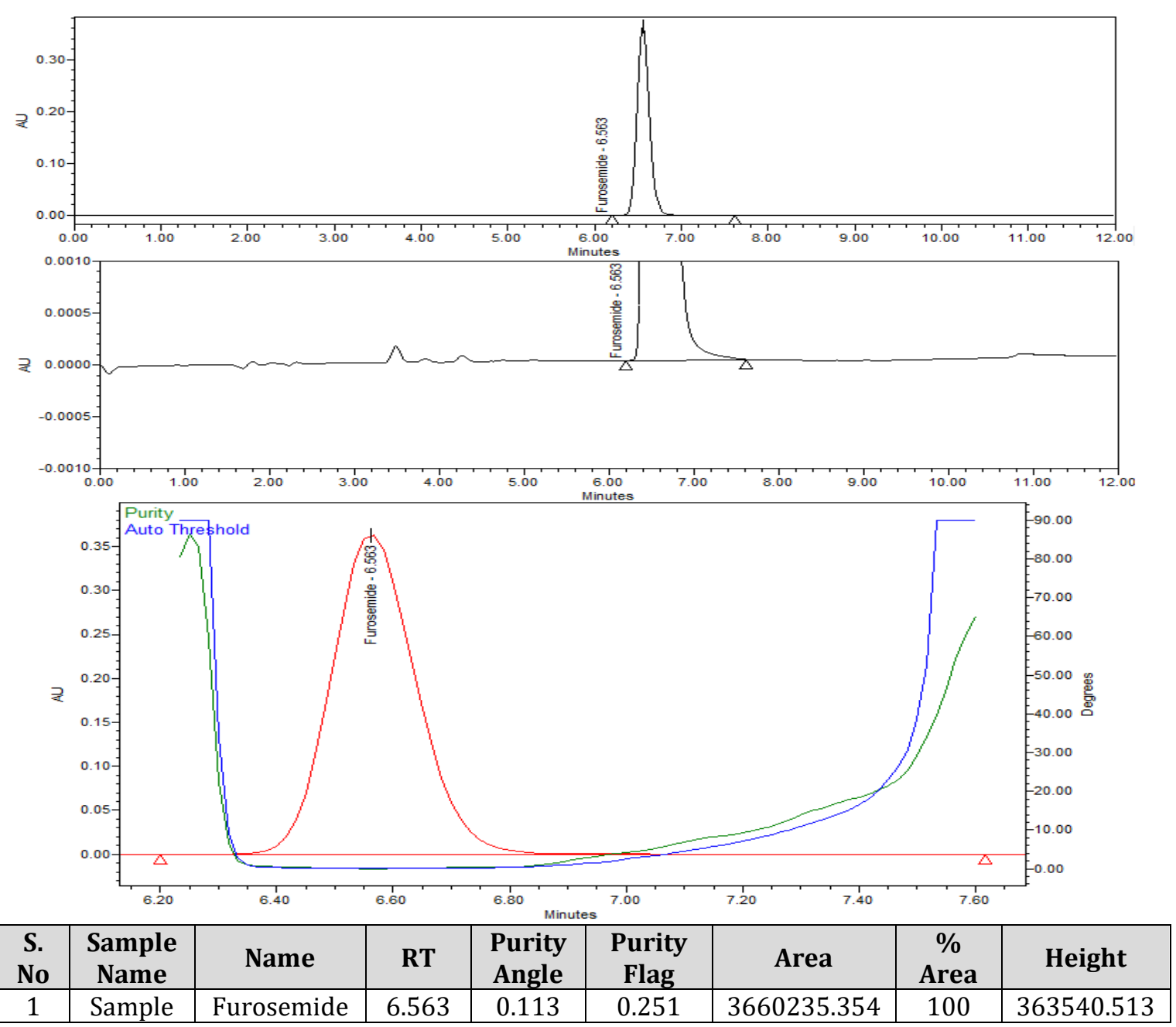

Figure 9. Chromatogram for sample solution of Furosemide.

\section{Robustness}

The robustness of the experimented method was established by varying the flow rate $(0.9 \mathrm{~mL} / \mathrm{min}, 1.0 \mathrm{~mL} / \mathrm{min}$ and $1.1 \mathrm{~mL} / \mathrm{min})$, mobile phase composition ratio $(50: 50 \% \mathrm{v} / \mathrm{v}$, $55: 45 \% \mathrm{v} / \mathrm{v}$ and $45: 55 \% \mathrm{v} / \mathrm{v})$ and column temperature $\left(20^{\circ} \mathrm{C}, 25^{\circ} \mathrm{C}\right.$, and $\left.30{ }^{\circ} \mathrm{C}\right)$. Those variations caused a slight deviation in percentage of recovery but the percentage of RSD values were found less than 2 in all conditions. The low percentage of RSD value indicates that the method is robust e.g. Table 7.

\section{Ruggedness}

Ruggedness of the method was performed by the analysis of formulation was done by two different analysts. The percentage purity of Furosemide for analyst 1 and analyst 2 were found to be $103.56 \pm 0.6547$ and $103.24 \pm 0.7661$, respectively. The percentage of RSD value for analyst 1 and analyst 2 for Furosemide were found to be 0.6322 and 0.7420 respectively. The low percentage of RSD values indicates that the method was more rugged e.g. Table 8. 


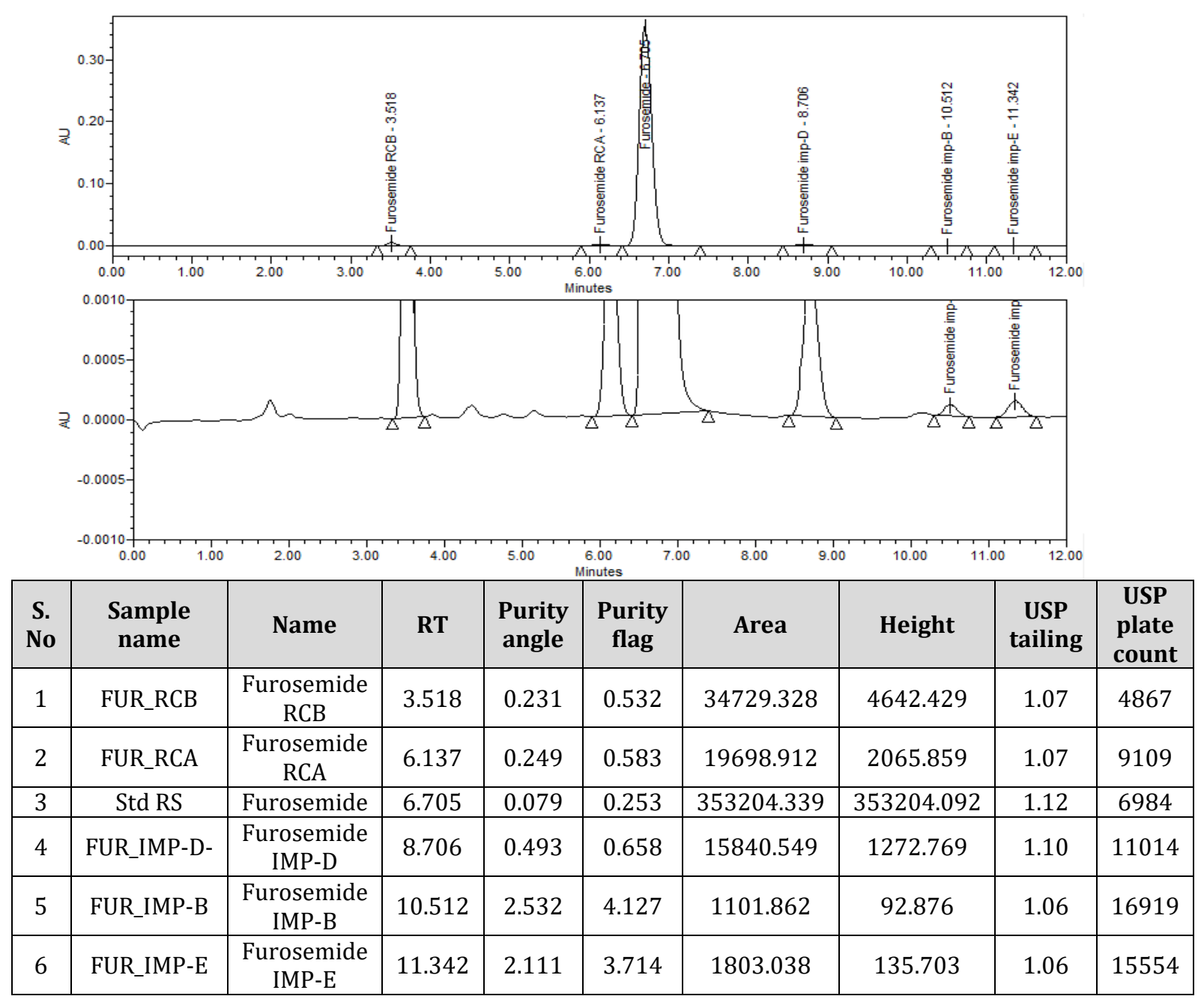

Figure 10. Chromatogram for impurities spiked in standard solution of Furosemide.

Table 7. Results for robustness study.

\begin{tabular}{|c|c|c|c|c|c|}
\hline \multirow[t]{2}{*}{ Parameter } & \multirow[t]{2}{*}{ Conditions } & \multicolumn{2}{|c|}{$\begin{array}{l}\text { Average peak area of } \\
\text { Furosemide }\end{array}$} & \multirow[t]{2}{*}{ \% Assay * } & \multirow[t]{2}{*}{ \% RSD } \\
\hline & & Standard & Sample & & \\
\hline \multirow{3}{*}{ Flow rate } & Low flow rate & 3780255.755 & 3782865.746 & 100.82 & \multirow{3}{*}{0.2676} \\
\hline & Nominal & 3400439.190 & 3385100.152 & 100.30 & \\
\hline & High flow rate & 3100555.005 & 3090845.981 & 100.44 & \\
\hline \multirow{3}{*}{$\begin{array}{l}\text { Mobile phase } \\
\text { composition }\end{array}$} & $\begin{array}{c}\text { Low mobile phase } \\
\text { composition }\end{array}$ & 3381930.753 & 3378959.938 & 100.79 & \multirow{3}{*}{0.1494} \\
\hline & Nominal & 3353972.474 & 3351734.774 & 100.49 & \\
\hline & $\begin{array}{c}\text { High mobile phase } \\
\text { composition }\end{array}$ & 3374796.275 & 3401848.426 & 100.66 & \\
\hline \multirow{3}{*}{$\begin{array}{l}\text { Column } \\
\text { temperature }\end{array}$} & $\begin{array}{l}\text { Low column } \\
\text { temperature }\end{array}$ & 3417205.184 & 3412681.502 & 100.62 & \multirow{3}{*}{0.1609} \\
\hline & Nominal & 3400439.190 & 3385100.152 & 100.30 & \\
\hline & $\begin{array}{l}\text { High column } \\
\text { temperature }\end{array}$ & 3415371.350 & 3403927.880 & 100.42 & \\
\hline
\end{tabular}

* Mean of six observations. 
Table 8. Ruggedness.

\begin{tabular}{|c|c|c|c|c|c|}
\hline Analyst & \% assay * & SD & \% RSD & SE & CI \\
\hline I & 103.56 & 0.6547 & 0.6322 & 0.2672 & $\begin{array}{c}102.87 \\
\text { to } \\
104.25\end{array}$ \\
\hline II & 103.24 & 0.7661 & 0.7420 & 0.3127 & $\begin{array}{c}102.43 \\
\text { to } \\
104.04\end{array}$ \\
\hline
\end{tabular}

* Mean of six observations.

\section{Solution stability}

Standard solution and Sample matrix are stable upto $60 \mathrm{~h}$ when stored in HPLC auto sampler at $15{ }^{\circ} \mathrm{C}$ and are stable up to $24 \mathrm{~h}$ when stored at room temperature. Also confirmed that the seal wash, needle wash, diluent and mobile phase used in this method are stable upto $60 \mathrm{~h}$ when stored at room temperature. Percentage of RSD was found to be within the limit e.g. Table 9 and 10.

Table 9. Solution stability for standard and sample solution at $15^{\circ} \mathrm{C}$.

\begin{tabular}{|c|c|c|c|c|c|c|}
\hline \multirow{2}{*}{$\begin{array}{l}\text { Time } \\
\text { interval }\end{array}$} & \multicolumn{2}{|c|}{ Retention time (min) } & \multicolumn{2}{|c|}{$\begin{array}{c}\text { Average peak area of } \\
\text { Furosemide }\end{array}$} & \multicolumn{2}{|c|}{$\%$ RSD } \\
\hline & Standard & Sample & Standard & Sample & Standard & Sample \\
\hline Initial & 7.036 & 7.035 & 3385100.152 & 3345074.348 & \multirow{7}{*}{0.3703} & \multirow{7}{*}{0.3126} \\
\hline $\begin{array}{l}\text { About } \\
3 \text { rd h }\end{array}$ & 7.036 & 7.035 & 3376658.274 & 3339752.328 & & \\
\hline $\begin{array}{l}\text { About } \\
15 \text { th h }\end{array}$ & 7.037 & 7.035 & 3409010.344 & 3380453.005 & & \\
\hline $\begin{array}{l}\text { About } \\
\text { 28th h }\end{array}$ & 7.041 & 7.036 & 3418492.643 & 3392899.275 & & \\
\hline $\begin{array}{l}\text { About } \\
\text { 36th h }\end{array}$ & 7.041 & 7.038 & 3418718.469 & 3404443.256 & & \\
\hline $\begin{array}{l}\text { About } \\
48 \text { th h }\end{array}$ & 7.042 & 7.036 & 344733.975 & 3398285.523 & & \\
\hline $\begin{array}{l}\text { About } \\
60 \text { th h }\end{array}$ & 7.042 & 7.038 & 3455748.686 & 3405545.302 & & \\
\hline
\end{tabular}


Table 10. Solution stability for standard and sample solution at room temperature.

\begin{tabular}{|c|c|c|c|c|c|c|}
\hline \multirow{2}{*}{$\begin{array}{c}\text { Time } \\
\text { interval }\end{array}$} & \multicolumn{2}{|c|}{ Retention time (min) } & \multicolumn{2}{c|}{$\begin{array}{c}\text { Average peak area of } \\
\text { Furosemide }\end{array}$} & \multicolumn{2}{c|}{ \% RSD } \\
\cline { 2 - 5 } & Standard & Sample & Standard & Sample & Standard & Sample \\
\hline Initial & 7.035 & 7.035 & 3376217.247 & 7.035 & & \\
\hline $\begin{array}{c}\text { About } \\
\text { 4th h }\end{array}$ & 7.035 & 7.036 & 3376554.314 & 7.036 & & \\
\hline $\begin{array}{c}\text { About } \\
\text { 8th h }\end{array}$ & 7.037 & 7.035 & 3413419.517 & 7.035 & & \\
\hline $\begin{array}{c}\text { About } \\
\text { 12th h }\end{array}$ & 7.040 & 7.036 & 3418675.595 & 7.036 & \multirow{2}{*}{0.3430} & \multirow{2}{*}{0.3219} \\
\hline $\begin{array}{c}\text { About } \\
\text { 16th h }\end{array}$ & 7.041 & 7.038 & 3419036.385 & 7.038 & & \\
\hline $\begin{array}{c}\text { About } \\
\text { 20th h }\end{array}$ & 7.042 & 7.036 & 3448420.891 & 7.036 & & \\
\hline $\begin{array}{c}\text { About } \\
\text { 24th h }\end{array}$ & 7.042 & 7.038 & 3454098.739 & 7.038 & & \\
\hline
\end{tabular}

\section{Conclusion}

In the present research, the developed method was validated as per the parameter mentioned in the ICH guidelines. It gives significant results and was found within the limit. When compared to all the reported methods, the shorter run time of this method will significantly reduce the analysis time, solvent consumption and all the impurities were separated well. Hence, it can be concluded that the proposed HPLC method is considered as simple, easy, fast, accurate and cost effective method for the analysis of FUR in Furosemide injection in the presence of impurities. Hence, the method could be effectively applied for the routine quality control analysis of FUR in Furosemide injection without any interference.

\section{Acknowledgement}

The authors are very much thankful to Dr. G. Murugananthan, Principal, Swamy Vivekanandha, College of Pharmacy, Tiruchengode, for his support and also thankful to the management for providing the necessary facilities to carry out the research work successfully.

\section{Conflicts of interest}

The author declares that they have no conflict of interest.

\section{References}

Alfred-Ugbenbo, D.; Zdoryk, O. A.; Georgiyants, V. A. Validation of analytical method for determination of Furosemide in extemporaneous syrup. Medical and Clinical Chemistry, v. 19, no. 2, p. 5-1, 2017. https://doi.org/10.11603/mcch.2410-681X.2017.v0.i2.7859

Amin, M. K. R.; Patel, D. R.; Shah, R. J.; Amin, J. M.; Jain, N.; Jain, D. K. Estimation of Amiloride and Furosemide in human plasma using high performance liquid chromatography. Der Pharmacia Sinica, v. 1, no. 3, p. 117-125, 2010. 
Bove, T.; Belletti, A.; Putzu, A.; Pappacena, S.; Denaro, G.; Landoni, G.; Bagshaw, S. M.; Zangrillo, A. Intermittent Furosemide administration in patients with or at risk for acute kidney injury: Meta-analysis of randomized trials. PLoS ONE, v. 13, no. 4, p. 1-18, 2018. https://doi.org/10.1371/journal.pone.0196088

BP - British Pharmacopoeia Commission Office. British Pharmacopoeia. London: British Pharmacopoeia, 2011.v. 1. p. 978-979.

Brayfield, A. E. Martindale: The complete drug reference. 37. ed. New York: Pharmaceutical Press, 2011. v. A. p. 1421-1422.

Brunton, L. Goodman \& Gilman's: The pharmacological basics of therapeutics. 12. ed. New York: McGraw Hill, 2011.

Chawla, L. S.; Davison, D. L.; Brasha-Mitchell, E.; Koyner, J. L.; Arthur, J. M.; Shaw, A. D.; Tumlin, J. A.; Trevino, S. A.; Kimmel, P. L.; Seneff, M. G. Development and standardization of a Furosemide stress test to predict the severity of acute kidney injury. Critical Care, v. 17, R-207, p. 1-9, 2013. https://doi.org/10.1186/cc13015

Chinaka, C. N.; Nwachukwu, N. Comparative in vitro quality assessment of five brands of Furosemide tablets marketed in Port Harcourt, Nigeria. Nigerian Journal of Pharmaceutical Research, v. 13, no. 2, p. 97-104, 2017.

Code Q2 (R1) ICH Guideline. Text on validation of analytical procedure. Canada: ICH Guidelines, 2015.

Costa, L. F.; Alcanfor, S. K. B.; Oliveira, A. L. Desenvolvimento e validação de método de quantificação de Furosemida por RMN de ${ }^{1} \mathrm{H}$. Revista Virtual de Química, v. 8, no. 5, p. 1683-1692, 2016.

Darweesh, A. S. Simultaneous determination of Sulfanilamide and Furosemide by using derivative spectrophotometry. Ibn Al-Haitham Journal for Pure \& Applied Sciences, v. 29 , no. 2, p. 240-253, 2016.

Dhayat, N. A.; Gradwell, M. W.; Pathare, G.; Anderegg, M.; Schneider, L.; Luethi, D.; Mattmann, C.; Moe, O. W.; Vogt, B.; Fuster, D. G. Furosemide/Fludrocortisone test and clinical parameters to diagnose incomplete distal renal tubular acidosis in kidney stone formers. Clinical Journal of American Society of Nephrology, v. 12, no. 9, p. 1507-1517, 2017. https://doi.org/10.2215/cjn.01320217

Duffy, M.; Jain, S.; Harrell, N.; Kothari, N.; Reddi, A. S. Albumin and Furosemide combination for management of edema in Nephrotic Syndrome: A review of clinical studies. Cells, v. 4, p. 622-630, 2015. https://www.mdpi.com/2073-4409/4/4/622

EDQM - European Directorate for the Quality of Medicines \& Health Care. European Pharmacopoeia. 8. ed. France: EDQM, 2014. v. 2. p. 2309-2310.

Gahandule, M.; Banerjee, S. K. Development of UV spectrophotometric methods and validation for estimation of Furosemide in bulk and tablet dosage form by absorbance maxima and Area Under the Curve Method. International Journal of Advances in Pharmaceutics, v. 5, no. 6, p. 160-170, 2016.

Gallignani, M.; Rondon, R. A.; Ovalles, J. F.; Brunetto, R. M. Transmission FTIR derivative spectroscopy for estimation of Furosemide in raw material and tablet dosage form. Acta Pharmaceutica Sinica B, v. 4, no. 5, p. 376-383, 2014. https://doi.org/10.1016/ j.apsb.2014.06.013 
Gandhi, S.; Mosleh, W.; Myers, R. B. H. Hypertonic saline with Furosemide for the treatment of acute congestive heart failure: A systematic review and meta-analysis. International Journal of Cardiology, v. 173, p. 139-145, 2014. https://doi.org/10.1016/j.ijcard. 2014.03.020

Gu, G.; Zhang, Y.; Lu, R.; Cul, W. Additional furosemide treatment beyond saline hydration for the prevention of contrast-induced nephropathy: A meta-analysis of randomized controlled trials. International Journal of Clinical and Experimental Medicine, v. 8, no. 1, p. 387-394, 2015.

Gulbis, B. E.; Spencer, A. Efficacy and safety of a Furosemide continuous infusion following cardiac surgery. Annals Pharmacotherapy, v. 40, p.1797-1803, 2006. https://doi.org/10.1345/aph.1g693

Haddock, B.; Larsson, H. B. W.; Francis, S.; Andersen, U. B. Human renal response to Furosemide: Simultaneous oxygenation and perfusion measurements in cortex and medulla. Acta Physiologica, v. 227, no. 1, e13292, 2019. https://doi.org/10.1111/ apha.13292

Hashemian, F.; Ghorbanian, M. A.; Hashemian, F.; Mortazav, S. A.; Sheikhi, M.; Jahanshahi, J.; Poorolajal, J. Effect of topical Furosemide on rhinosinusal polyposis relapse after endoscopic sinus surgery a randomized clinical trial. JAMA Otolaryngology - Head \& Neck Surgery, v. 142, no. 11, p.1045-1049, 2016. https://doi.org/10.1001/jamaoto. 2016.1249

Ho, K. M.; Power, B. M. Benefits and risks of Furosemide in acute kidney injury. Anaesthesia, v. 65, p. 283-293, 2010. https://doi.org/10.1111/j.1365-2044.2009.06228.x

IP - The Indian Pharmacopoeia Commission. Indian Pharmacopoeia. 8. ed. Ghaziabad: The Indian Pharmacopoeia Commission, 2018. v. 2. p. 133-2135.

Kaynak, M. S.; Sahln, S. Development and validation of a RP-HPLC method for determination of solubility of Furosemide. Turkish Journal of Pharmaceutical Sciences, v. 10 , no. 1, p. 25-34, 2013.

Kher, G.; Ram, V. R.; Kher, M.; Hitendra, J. Development and validation of a HPTLC method for simultaneous determination of Furosemide and Spironolactone in its tablet formulation. Research Journal of Pharmaceutical, Biological and Chemical Sciences, v. 4, no. 1, p. 365-377, 2013.

Kitsios, G. D.; Mascari, P.; Ettunsi, R.; Gray, A. W. Co-administration of Furosemide with albumin for overcoming diuretic resistance in patients with hypoalbuminemia: A meta-analysis. Journal of Critical Care, v. 4, no. 29, p. 253-259, 2014. https://doi.org/ 10.1016/j.jcrc.2013.10.004

Kumari, R.; Dubey, V.; Alam, S.; Singh, S. N. S.; Singh, R. Development analytical and validation of RP-HPLC method for simultaneous estimation of Amiloride Hydrochloride and Furosemide as API in their combined tablet dosage form. World Journal of Pharmacy and Pharmaceutical Sciences, v. 7, no. 3, p. 794-807, 2018.

Labriola, L.; Olinger, E.; Belge, H.; Pirson, Y.; Dahan, K.; Devuyst, O. Paradoxical response to Furosemide in uromodulin-associated kidney disease. Nephrology Dialysis Transplantation, v. 30, p. 330-335, 2015. https://doi.org/10.1093/ndt/gfu389

Liu, P.; McMenamin, Ú. C.; Spence, A. D.; Johnston, B. T.; Coleman, H. G.; Cardwell, C. R. Furosemide use and survival in patients with esophageal or gastric cancer: A population-based cohort study. BMC Cancer, v. 19, 1017, p.1-12, 2019. https://doi.org/10.1186/s12885-019-6242-8 
Lovett, L.; Nygard, G.; Dura, P.; Khalil S. K. W. An improved HPLC method for the determination of Furosemide in plasma and urine. Journal of Liquid Chromatography, v. 8, no. 9, p. 1611-1628, 1985. https://doi.org/10.1080/01483918508074082

Lumlertgul, N.; Peerapornratana, S.; Trakarnvanich, T.; Pongsittisak, W.; Surasit, K.; Chuasuwan, A.; Tankee, P.; Tiranathanagul, K.; Praditpornsilpa, K.; Tungsanga, K.; Eiam-Ong, S.; Kellum, J. A.; Srisawat, N. Early versus standard initiation of renal replacement therapy in Furosemide stress test non-responsive acute kidney injury patients (the FST trial). Critical Care, v. 22, Article number: 101, p. 1-9, 2018. https://doi.org/ 10.1186/s13054-018-2021-1

Mannam, R.; Yallamalli, I. M. RP-HPLC method for estimation of Furosemide in rabbit plasma. Journal of Chemical and Pharmaceutical Research, v. 10, no. 2, p. 1-5, 2018.

Matsue, Y.; Damman, K.; Voors, A. A.; Kagiyama, N.; Yamaguchi, T.; Kuroda, S.; Okumura, T.; Kida, K.; Mizuno, A.; Oishi, S.; Inuzuka, Y.; Akiyama, E.; Matsukawa, R.; Kato, K.; Suzuki, S.; Naruke, T.; Yoshioka, K.; Miyoshi, T.; Baba, Y.; Yamamoto, M.; Murai, K.; Mizutani, K.; Yoshida, K.; Kitai, T. Time-to-Furosemide treatment and mortality in patients hospitalized with acute heart failure. Journal of the American College of Cardiology, v. 69, no. 25, p. 3042-3051, 2017. https://doi.org/10.1016/j.jacc.2017.04.042

Maulik, B.; Ketan, D.; Shital, F. Development and validation of RP-HPLC method for simultaneous estimation of Furosemide and Spironolactone in their combined tablet dosage form. Journal of Pharmaceutical Science and Bioscientific Research, v. 2, no. 3, p. 144-147, 2012.

Mose, F. H.; Jörgensen, A. N.; Vrist, M. H.; Ekelöf, N. P.; Pedersen, E. B.; Bech, J. N. Effect of $3 \%$ saline and furosemide on biomarkers of kidney injury and renal tubular function and GFR in healthy subjects: A randomized controlled trial. BMC Nephrology, v. 20, Article number: 200, 2019. https://doi.org/10.1186/s12882-019-1342-X

Najib, N.; Idkaidek, N.; Beshtawi, M.; Bader, M.; Admour, I.; Alam, S. M.; Zaman, Q.; Dham, R. Bioequivalence evaluation of two brands of Furosemide $40 \mathrm{mg}$ tablets (Salurin and Lasix) in healthy human volunteers. Biopharmaceutics \& Drug Disposition, v. 24, p. 245-249, 2003. https://doi.org/10.1002/bdd.361

Naveed, S.; Qamar, F.; Zainab, S. Simple UV spectrophotometric assay of Furosemide. Journal of Innovations in Pharmaceuticals and Biological Sciences, v. 1, no. 3, p. 97-101, 2014.

Patil, S. R.; Kumar, L.; Kohli, G.; Bansal. A. K. Validated HPLC method for concurrent determination of Antipyrine, Carbamazepine, Furosemide and Phenytoin and its application in assessment of drug permeability through Caco-2 cell monolayers. Scientia Pharmaceutica, v. 80, no. 1, p. 89-100, 2012. https://doi.org/10.3797/scipharm.1109-03

Phale, M. Stress degradation studies of Furosemide and development and validation of Siam RP-HPLC Method for its quantification. World Journal of Pharmacological Research, v. 6, no. 1, p. 905-920, 2017.

Ram, R. R.; Ram, V. R.; Joshi, H.S. Analytical method validation of simultaneous determination of Spironolactone and Furosemide in tablet formulation and its statistical evaluation. International Letters of Chemistry, Physics and Astronomy, v. 42, p. 25-35, 2014. https://doi.org/10.18052/www.scipress.com/ILCPA.42.25 
Ram, V. R.; Dave, P. N.; Joshi, H.S. Development and validation of a stability-indicating HPLC assay method for simultaneous determination of Spironolactone and Furosemide in tablet formulation. Journal of Chromatographic Science, v. 50, p. 721-726, 2012. https://doi.org/10.1093/chromsci/bms062

Rani, G. D.; Rani, A. R.; Venkateswarlu, P. Spectrophotometric determination of Furosimide in pharmaceutical formulations by charge transfer complex method. International Journal of ChemTech Research, v. 10, no. 3, p. 666-670, 2017.

Reddy, A. S. S. V.; Ahmed, M. J.; Shetty, A. S. K. Simultaneous determination and validation of Spironolactone and Furosemide by Second Order Derivative Method and Area Under Curve Method in bulk drug and pharmaceutical formulations. International Journal of ChemTech Research, v. 5, no. 4, p. 1875-1885, 2013.

Roth, J.; Rapaka, R. S.; Prasad, V. K. An HPLC procedure for the analysis of Furosemide in pharmaceuticals-analysis of Furosemide tablets and Furosemide injection. Analytical Letters, v. 14, no. 13, p. 1013-1030, 1981. https://doi.org/10.1080/00032718108081445

Seth, S. D.; Seth, V. Textbook of Pharmacology. 3. ed. New Delhi: Elsevier, 2009.

Shaikh, B. Development and validation of a liquid chromatographic method for the determination of Furosemide, a diuretic, in bovine milk. Journal of Agricultural Food Chemistry, v. 43, p. 2117-2121, 1995.

Shaikh, S. J.; Rao, N. N. Simultaneous estimation and forced degradation studies of Amiloride Hydrochloride and Furosemide in a pharmaceutical dosage form using Reverse-Phase High-Performance Liquid Chromatography Method. Asian Journal of Pharmaceutical and Clinical Research, v. 11, no. 7, p. 215-221, 2018. https://doi.org/ 10.22159/ajpcr.2018.v11i7.25783

Sila-on, W.; Na-Ranong, S.; Rakrod, S.; Ornlaor, S.; Joungmunkong, Z. Development and validation of RP-HPLC method for determination of Acetazolamide, Furosemide and Phenytoin extemporaneous suspensions. Asian Journal of Pharmaceutical Sciences, v. 11, no. 1, p. 138-139, 2016. https://doi.org/10.1016/j.ajps.2015.11.087

Şimşek, F. Ö.; Kaynak, M. S.; Şanli, N.; Şahin, S. Determination of Amlodipine and Furosemide with newly developed and validated RP-HPLC Method in commercially available tablet dosage forms. Hacettepe University Journal of the Faculty Pharmacy, no. 2 , p. $145-158,2012$.

Sora, D. I.; Udrescua, Ş.; Albu, F.; David, V.; Medvedovici, A. Analytical issues in HPLC/MS/MS simultaneous assay of Furosemide, Spironolactone and Canrenone in human plasma samples. Journal of Pharmaceutical and Biomedical Analysis, v. 52, no. 5, p. 734-740, 2010. https://doi.org/10.1016/j.jpba.2010.03.004

Souza, A.; Kedor-Hackmann, E. R. M.; Santoro, M. I. R. M.; Aurora-Prado, M. S. Development of analytical method by free solution capillary electrophoresis for Furosemide under stress degradation. Separation Science Plus, v. 2, no. 7, p. 253-261, 2019.

Sullivan, S. L.; Whittem, T.; Morley, P. S.; Hinchcliff, K. W. A systematic review and meta-analysis of the efficacy of Furosemide for exercise-induced pulmonary haemorrhage in thoroughbred and standard bred racehorses. Equine Veterinary Journal, v. 47, p. 341-349, 2015.

Supriya, P.; Patel, S. G.; Dhobale, S. M. Estimation of Frusemide in bulk and tablet formulation by UV spectrophotometric Area Under Curve Method. International Research Journal of Science \& Engineering, v. A3, p. 96-100, 2018. 
Tandel, J. N. Development and Validation of RP-HPLC Method for the simultaneous determination of Amiloride Hydrochloride and Furosemide in pure and pharmaceutical dosage form. Eurasian Journal of Analytical Chemistry, v. 12, no. 4, p. 385-394, 2017.

USP-NF - The United States Pharmacopoeia-The National Formulary. The Official Compendia of Standards. Rockville, MD: The United Stated Pharmacopoeial Convention, 2008. v. 2.

Vasco, R. F. V.; Moyses, R. M. A.; Zatz, R. Elias, R. M. Furosemide increases the risk of hyperparathyroidism in chronic kidney disease. American Jourbnal of Nephrology, v. 43, p. 421-430, 2016. https://doi.org/10.1159/000446449

Widdifield, C. M.; Robson, H.; Hodgkinson, P. Furosemide's one little hydrogen atom: NMR crystallography structure verification of powdered molecular organics. Chemical Communication, v. 52, p. 6685-6688, 2016. https://doi.org/10.1039/C6CC02171A

Youm, I.; Youan, B.-B. C. Validated reverse-phase high-performance liquid chromatography for quantification of Furosemide in tablets and nanoparticles. Journal of Analytical Methods in Chemistry, v. 2013, Article ID 207028, p. 1-9, 2013. https://doi.org/10.1155/ 2013/207028

Zeng, B.; Nguyen, K.; Sherma, J. Development of quantitative HPTLC-densitometry methods following a model approach for transfer of TLC screening methods for pharmaceutical products of Atenolol, Chloramphenicol, Furosemide, Glibenclamide, Penicillin V Potassium, and Praziquantel. Journal of Liquid Chromatography \& Related Technologies, v. 41, no. 6, p. 324-332, 2018. https://doi.org/10.1080/10826076.2018.1448689 
License information: This is an open-access article distributed under the terms of the Creative Commons
Attribution License, which permits unrestricted use, distribution, and reproduction in any medium, provided the
original work is properly cited. 